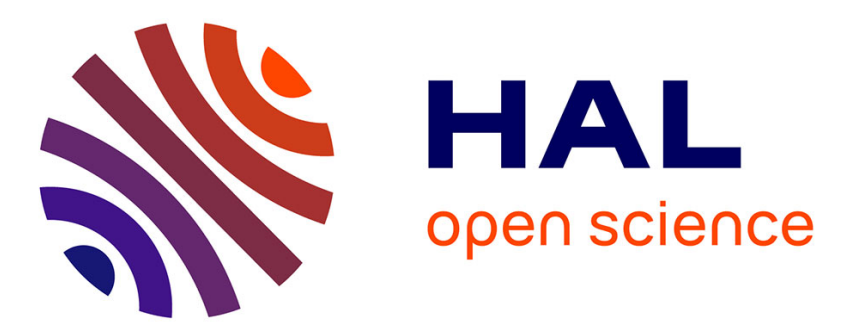

\title{
Channel profiles through the active thrust front of the southern Barbados prism.
}

Pascale Huyghe, Michel Foata, Eric Deville, Georges Mascle

\section{To cite this version:}

Pascale Huyghe, Michel Foata, Eric Deville, Georges Mascle. Channel profiles through the active thrust front of the southern Barbados prism.. Geology, 2004, 32(5), pp.429-432. 10.1130/G20000.1 . hal-00100378

\section{HAL Id: hal-00100378 https://hal.science/hal-00100378}

Submitted on 26 Sep 2006

HAL is a multi-disciplinary open access archive for the deposit and dissemination of scientific research documents, whether they are published or not. The documents may come from teaching and research institutions in France or abroad, or from public or private research centers.
L'archive ouverte pluridisciplinaire HAL, est destinée au dépôt et à la diffusion de documents scientifiques de niveau recherche, publiés ou non, émanant des établissements d'enseignement et de recherche français ou étrangers, des laboratoires publics ou privés. 


\title{
Channel profiles through the active thrust front of the southern Barbados prism
}

\author{
Pascale Huyghe*, Michel Foata \\ Maison des Géosciences, UMR Centre National de la Recherche Scientifique 5035, BP 53, 38041, \\ Grenoble, France \\ Eric Deville \\ Institut Français du Pé trole, 1 et 4, Avenue de Bois-Préau, 92852 Rueil-Malmaison, France \\ Georges Mascle \\ Maison des Géosciences, UMR Centre National de la Recherche Scientifique 5035, BP 53, 38041, \\ Grenoble, France \\ Caramba Working Group $\dagger$ \\ *E-mail: huyghe@ujf-grenoble.fr. \\ †R. Cagna (Genavir-Brest), Y. Callec (Institut Français du Pétrole), G. Desaubliaux (Institut Français du Pétrole), N. Ellouz (Institut Français du \\ Pétrole), R. Griboulard (Université de Bordeaux), S.H. Guerlais (Université de Cergy-Pontoise), S. Lallemant (Université de Cergy-Pontoise), F. \\ Lebrun (Université Antilles-Guyanes), A. Mascle (Institut Français du Pétrole), J.L. Mugnier (Université de Grenoble), C. Padron (Université de \\ Grenoble), A. Prinzhofer (Institut Français du Pétrole), J. Schmitz (Institut Français du Pétrole), E. Wendenbaum (Université de Grenoble).
}

\begin{abstract}
Submarine channels of the Orinoco River were analyzed using high-quality, dense coverage bathymetric and seismic data provided by a recent marine survey on the southern Barbados prism. Analysis of the syntectonic sediments on seismic profiles shows that the four to five frontmost structures show evidence of recent tectonic movement. Slope analysis of the major channels was performed. From their headwaters to domains of little or no active tectonics, the channels display, $0.2 \%$ slope and form levees. Slope and incision increase gradually in domains of moderate tectonics, but deep canyons with $; 2 \%$ mean slope form where the channels cross the active frontal folds of the prism. Detailed correlation between the active structures, their geometry, and canyon slope suggest that systematic variations in channel gradient highlight variations in substrate uplift rate. Steep slopes induced by uplift accelerate sediment flow and enhance incision. Nonetheless, such slope analysis is subject to complications introduced by variations in sediment flux and transient erosional conditions.
\end{abstract}

Keywords: channel slope, submarine canyon, active tectonics, southern Barbados prism.

\section{INTRODUCTION}

The occurrence and formation of submarine channels have been studied in various settings (Twichell and Roberts, 1982; Klaus and Taylor, 1991; Orange et al., 1994; Pratson and Coakley, 1996). However, very few studies deal with tectonic control of the morphology of submarine channels. In contrast, numerous studies have treated the influence of tectonics in subaerial fluvial systems, focusing on quantitative descriptions of channel morphology as well as incision and transport processes (e.g., Tinkler and Wohl, 1998), and developing models (e.g., Howard et al., 1994; Whipple and Tucker, 1999). Some morphological parameters

of channels (slope, concavity, width, incision, sinuosity) have been used to quantify the channel response to tectonics in active settings (Harbor, 1998; Snyder et al., 2000; Kirby and Whipple, 2001).

We present the results of a study on the influence of tectonics on the morphology of major submarine channels. We have analyzed longitudinal bathymetric profiles of channels to study active deformation in the southern Barbados prism. High-quality, dense-coverage bathymetric data and $5300 \mathrm{~km}$ of seismic and $3.5 \mathrm{kHz}$ acoustic data (Fig. 1) were acquired in this area by the IFREMER marine survey Caramba in January 2002 (Mascle, 2002), and .120-km-long, nonlinear submarine channels from the Orinoco River have been documented.

\section{GEOLOGIC SETTING AND RECENT TECTONICS OF THE SOUTHERN BARBADOS PRISM}

The Barbados Ridge Complex is developing as a result of the subduction of the North and South American plates beneath the Caribbean plate since the middle Eocene (Peter and Westbrook, 1976). The Caribbean plate moves approximately due east relative to South America at a rate of ;20 mm/yr along most of the plate boundary (Weber et 
al., 2001). Pure wrenching is concentrated along the eaststriking, seismically active El Pilar fault, whereas transpression occurs along the Central Range fault, which is oblique to local plate motion (Fig. 1). Toward the south, normal-fault systems affect the passive Guyana Margin, and the boundary between continental and oceanic crusts is not firmly established. Large volumes of sediments coming mainly from the Orinoco system are frontally accreted to the toe of the Barbados wedge. The coarsest turbiditic material (medium sands and gravels) coming from the Guyana Margin is funnelled down to the Atlantic Abyssal Plain through major channels feeding the Orinoco deep-sea fan (Belderson et al., 1984; Faugères et al., 1993), whereas the finest material (fine sands and clay) overflows the channels and deposits over the prism. As a result of the southerly location of the terrigenous source, the Barbados Ridge Complex narrows from $450 \mathrm{~km}$ at its southern extremity to $100 \mathrm{~km}$ north of $188 \mathrm{~N}$, whereas its thickness varies from $7000 \mathrm{~m}$ to $200 \mathrm{~m}$, from south to north (Moore et al., 1990).

The recent tectonics of the southern Barbados prism have been detected from seismic observations. The period covered by the term "recent" may represent ,500 k.y., considering the $0.1 \mathrm{~s}$ thickness of sediments inferred from seismic observations (Fig. 2A) and a sediment accumulation rate of more than $12 \mathrm{~cm} / \mathrm{k}$.y. (Faugères et al., 1993). We use the following criteria to map the active structures on the $5300 \mathrm{~km}$ of seismic profiles: thrust faults are considered active when they cut seismic reflectors within the upper $0.1-0.2 \mathrm{~s}$ two-way traveltime and reach the sea bottom and/or when syntectonic fans formed by recent sediments develop on the back limb of the fold-related thrust fault (Fig. 2A). We find that the two to five frontmost folds are active tectonic structures (Fig. 2B). They are related to the forward development of the major thrust system, where new blind thrusts deform the abyssal plain and out-ofsequence reactivation of the nearest thrusts occurs behind the new deformation (Huyghe et al., 1999). Some deformations are also occurring as far as $30-100 \mathrm{~km}$ from the toe of the prism. They are linked to diffuse strike-slip faulting (Mascle et al., 1990) or mud intrusions into preexisting structures, and produce local vertical uplift.

\section{MORPHOLOGY OF CHANNELS}

The headwaters of the major channels are diffuse and start from the continental slope of the Guyana margin (;1300 $\mathrm{m}$ water depth). The channels flow through a region of moderate to low slope with a general eastward trend, changing from northeast to eastsoutheast (Figs. 2 and 3) according to the main tectonic features (Mascle et al., 1990). At a smaller scale, the channels form meanders and are strongly influenced by anticlines and mud diapirs having prominent relief on the seafloor. The channels trend east to eastsoutheast as they cross the active frontal folds. They finally flow northeastward on the abyssal plain (;3500 m water depth), where they merge. Longitudinal profiles of the major channels a, b, and c (Fig. DR11) form the basis of our analysis. They were generated from 200-mresolution digital elevation models (software CARAIBES developed by IFREMER) produced from the bathymetric data that was acquired using an EM-12 multibeam system with a vertical accuracy of $0.6 \%$ of the depth. Pronounced variations in the channel slope (Fig. 3; Table DR1 [see footnote 1]) and transverse sections are observed depending upon their position within the prism. The alongstream evolution, however, is identical for the three channels. From the headwaters to domains of no or little active tectonic deformation (west of landmarks numbered 3 in Figs. 2B and $3 \mathrm{~A}$ ), the slope of the channels slightly decreases downstream, as is observed for subaerial streams. Nonetheless, the slope decrease is very small (,0.2\% for a .100-km-long profile), and an exponential law (Adams and Schlager, 2000; Goff, 2001) fails to describe the regional curvature of the profile. Levees, ,150 m high, form from the finest suspended turbiditic material that overflows the channels (Fig. 3B). In the domain of moderate reactivation (from landmark 3 downward), the channel slope gently increases (Table DR1 [see footnote 1] and Fig. 3C), and channel downcutting occurs by turbidite scouring (Pratson and Coakley, 1996). Cut terraces may form. Where channels cross the frontal active folds (from landmark 2 to the deformation front), their morphology turns into .300-m deep and ,150-m-wide canyons (Figs. 3D and 4). In this zone, mean channel slope abruptly increases, exceeding several percent

and inducing a 260-580 m overdeepening of the canyon at the deformation front (difference between the canyon depth and a linear extrapolation of the profile upstream of landmark 2; Fig. 3A; Table DR1 [see footnote 1]).

\section{CHANNEL PROFILES THROUGH THE ACTIVE THRUST FRONT}

Channels a, b, and c cross 4, 3, and 1 major active thrust faults, respectively. A detailed correlation between the geometry of structures observed from seismic profiles and canyon slope (Fig. 4) shows that the zone of enhanced slope (.1.9\%) for the three longitudinal profiles extends from the frontal thrust to the rear limb of the anticline related to innermost active structure. The width of the enhanced slope zone thus clearly correlates with recently active structures and varies from 30 to $10 \mathrm{~km}$. Along each canyon, a peak in slope occurs at the hanging wall of a single active thrust starting at the fault trace and reaching

a maximum value at a nearly constant distance $(3.5-2.7 \mathrm{~km})$ landward of the fault. This first order correlation between active structures and channel slope suggests that the increase of channel slope reflects an increase of the 
uplift rate, as inferred in subaerial fluvial systems (Seeber and Gornitz, 1981). The above rule applies systematically to slope variations in the southern Barbados canyons. From north to south, mean slopes are steeper and peaks in local slope are higher and thinner. These findings indicate that the deformation front is less mature in the south than in the north, because the deformation is more localized and the long-term deformation decreases. In detail, the peak in slope is localized in the hanging wall of the second thrust for canyons a and b. For the less-developed structures of canyons b and c, slope peaks are located above the frontal limb, whereas they are located on the flat crest of the anticline in the case of canyon a. The localization of the maximum slope in the hanging wall of the second thrust indicates that out-of-sequence reactivation is more active than frontal deformation. Furthermore, the localization of the slope peak above the frontal limb suggests a strong attenuation of the displacement along the thrust beneath the frontal structures. This implies a mode of folding more complex than passive fault-bend fold, fold-propagation fault, or fold amplification (Mugnier et al., 1993; Lickorish and Butler, 1996).

\section{CHANNEL RESPONSE TO TECTONIC FORCING}

The intuitive leap from observation of differences in channel slope that are correlated to active structures, to the interpretation that the slope reflects the uplift rate, requires assessment. In subaerial fluvial systems, the increase of gradient reflects the adjustment of channel to variable uplift rates, as incision tends to balance rock uplift (Kirby and Whipple, 2001). The applicability of this adjustment concept to the southern Barbados canyons is discussed in the following.

\section{Comparison Between Incision and Slope}

Incision at the base of a turbidite flow increases when its velocity increases (Mulder et al., 1998), and velocity is correlated to slope (Bagnold, 1962). Therefore the mechanics of turbidite currents predict a positive correlation between channel slope and incision. Uplifted frontal structures, by accelerating sediment flows, consequently enhance incision at the base of channels. The southern Barbados slope canyons thus adjust in response to tectonic forcing.

In subaerial systems, the incision of dated cut terraces allows testing the adjustment of rivers to uplift (Lave and Avouac, 2001). The narrow and flat surfaces located on the flanks of the Barbados canyons are presumably cut terraces (i.e., paleofloors of the canyon) and record a variable incision story. Nonetheless, without dating these cut terraces, the total incision (i.e., the difference between the depth of a canyon and its walls) is the only proxy for the incision rate. If a slight shift between maximum values of slopes and total incision seems to be related to a time evolution of the incision pattern, incision and slope correlate (Fig. 4).

\section{Canyon Evolution: From Active to Passive Markers}

Canyons in active settings may be considered as active markers as long as erosion by turbidite scouring occurs. Therefore, canyons a, b, and c cannot be considered as passive markers deformed over growing folds. Nonetheless, local negative slope located above the backlimb of the innermost active structure is observed in canyon a (Fig. 4). We suggest that erosion does not balance the back tilting due to the fold development, probably because of low turbidite flux. If the turbidite flux decreases, active frontal folds will finally form dams to the course of the channel. This is observed for an older abandoned passively deformed canyon, north of channel a (Fig. 2B). Abandonment may have been caused by a low turbidity flux linked to a greater course to the deformation front, upon an only slightly inclined slope.

\section{Can Steady-State Incision be Inferred?}

Our observations suggest that a recent active fault induces a knickpoint that migrates upward and widens, as inferred for mediumscale rivers (Rosenbloom and Anderson, 1994). The localized knickpoint and the local negative slopes in canyon a do not reflect steady-state conditions between uplift and erosion. This lack of dynamic equilibrium could be related to the decrease of erosion linked to turbidite scouring. During interglacial stages and at present, sediments are essentially trapped at depositionally high levels in deltas and transgressive systems tracts (Kolla and Macurda, 1988), and canyons are less active. Recent studies (e.g., Pazzaglia and Brandon, 2001) suggest that a subaerial profile appears relatively steady only when averaged over time scales longer than the glacial climate cycle (;100 k.y.).

\section{CONCLUSION}

We here applied a slope analysis method to submarine channels of the southern Barbados prism. Our results indicate that uplift exerts a fundamental control on submarine-channel gradient, analogous to subaerial streams. Systematic variations in channel gradient highlight variations in uplift rate and reflect the distribution and kinematics of active structures. This new approach to submarine tectonic geomorphology is powerful in active convergent settings. These preliminary results suggest that canyon morphology will furnish in the future a better understanding of uplift patterns in accretionary wedge and submarine erosion processes. Nonetheless, such slope analysis is subject 
to complications introduced by variations in sediment flux and transient erosional conditions. Further work on submarine incision needs to be developed before it can be systematically applied.

ACKNOWLEDGMENTS

We are grateful to E. Kirby, H.J. Tobin, and D. Orange for constructive reviews.

REFERENCES CITED

Adams, E.W., and Schlager, W., 2000, Basic types of submarine slope curvature: Journal of Sedimentary Research, v. 70, p. 814-828.

Bagnold, R.A., 1962, Auto-suspension of transported sediments: Turbidity currents: Royal Society of London Proceedings, ser. A, v. 265, p. 315-319.

Belderson, R.H., Kenyon, N.H., Stride, A.H., and Pelton, C.D., 1984, A “braided”' distributary system on the Orinoco deep-sea fan: Marine Geology, v. 56, p. 195-206.

Faugères, J.C., Gonthier, E., Griboulard, R., and Massé, L., 1993, Quaternary sandy deposits and canyons on the Venezuelan margin and south Barbados accretionary prism: Marine Geology, v. 110, p. 115-142.

Goff, J.A., 2001, Quantitative classification of canyon systems on continental slopes and a possible relationship to slope curvature: Geophysical Research Letters, v. 28, p. 4359-4362.

Harbor, D.J., 1998, Dynamic equilibrium between an active uplift and the Sevier River, Utah: Journal of Geology, v. 106, p. 181-194.

Howard, A.D., Seidl, M.A., and Dietrich, W.E., 1994, Modeling fluvial erosion on regional to continental scales: Journal of Geophysical Research, v. 99, p. 13,971-13,986.

Huyghe, P., Mugnier, J.L., Griboulard, R., Deniaud, Y., Gonthier, E., and Fauge res, J.C., 1999, Review of the tectonic controls and sedimentary patterns in late Neogene piggyback basins on the Barbados Ridge Complex, in Mann, P., ed., Caribbean basins: Amsterdam, Elsevier, p. 369-388.

Kirby, E., and Whipple, K., 2001, Quantifying rockuplift rates via stream profile analysis: Geology, v. 29, p. 415418.

Klaus, A., and Taylor, B., 1991, Submarine canyon development in the Izu-Bonin forearc; a SeaMarc II and seismic survey of Aoga Shima Canyon: Marine Geophysical Researches, v. 13, p. 105-130.

Kolla, V., and Macurda, D.B., 1988, Sea-level changes and timing of turbidity-current events in deep-sea fan systems, in Wilgus, C.K., et al., eds., Sea-level changes-An integrated approach: Society of Economic Paleontologists and Mineralogists Special Publication 42, p. 381-392.

Lave', J., and Avouac, J.P., 2001, Active folding of fluvial terraces across the Siwalik Hills, Himalayas of central Nepal: Journal of Geophysical Research, v. 106, p. 25,561-25,593.

Lickorish, W.H., and Butler, R., 1996, Fold amplification and parasequence stacking patterns in syntectonic shoreface carbonates: Geological Society of America Bulletin, v. 108, p. 966-977.

Mascle, A., 2002, Caramba Cruise Report, Ifremer Babs.]: http://www.ifremer.fr/sismer/catal/campagne/campagne.htql?crno 52010010.

Mascle, A., Endignoux, L., and Chennouf, T., 1990, Frontal accretion and piggyback basin development at the southern edge of the Barbados Ridge accretionary complex, in Mascle A., Moore, J.C., et al., Proceedings of the Ocean Drilling Program, Scientific results, Volume 110: College Station, Texas, Ocean Drilling Program, p. 17-28.

Moore, J.C., Mascle, A., et al., 1990, Proceedings of the Ocean Drilling Program, Scientific results, Volume 110: College Station, Texas, Ocean Drilling Program, 448 p.

Mugnier, J.L., Mascle, G., and Faucher, T., 1993, Structure of the Siwaliks of western Nepal: An intracontinental accretionary prism: International Geology Review, v. 35, p. 32-47.

Mulder, T., Syvitski, J.P.M., and Skene, K.I., 1998, Modelling erosion and deposition by turbidity currents generated at river mouths: Journal of Sedimentary Research, v. 68, p. 124-137.

Orange, D.L., Anderson, R.S., and Breen, N.A., 1994, Regular canyon spacing in the submarine environment: The link between hydrology and geomorphology: GSA Today, v. 4, p. 36-39.

Pazzaglia, F., and Brandon, M., 2001, A fluvial record of long-term steady-state uplift and erosion across the Cascadia forearc high, western Washington State: American Journal of Science, v. 301, p. 385-431.

Peter, G., and Westbrook, G.K., 1976, Tectonics of southwestern North Atlantic and Barbados Ridge Complex: American Association of Petroleum Geologists Bulletin, v. 60, p. 1078-1106.

Pratson, L.F., and Coakley, B.J., 1996, A model for the headward erosion of submarine canyons induced by downslope-eroding sediment flows: Geological Society of America Bulletin, v. 108, p. 225-234.

Rosenbloom, N.A., and Anderson, R.S., 1994, Hillslope and channel evolution in a marine terraced landscape, Santa Cruz, California: Journal of Geophysical Research, v. 99, p. 14,013-14,029. 
Seeber, L., and Gornitz, V., 1981, River profiles along the Himalayan arc as indicators of active tectonics: Tectonophysics, v. 92, p. 335-367.

Snyder, N.P., Whipple, K.X., Tucker, G.E., and Merritts, D.J., 2000, Landscape response to tectonic forcing: Digital elevation model analysis of stream profiles in the Mendocino triple junction region, northern California: Geological

Society of America Bulletin, v. 112, p. 1250-1263.

Tinkler, K.J., and Wohl, E.E., eds., 1998, Rivers over rock: Fluvial processes in bedrock channels: American Geophysical Union Geophysical Monograph 107, 323 p.

Twichell, D.C., and Roberts, D.G., 1982, Morphology, distribution, and development of submarine canyons on the United States Atlantic continental slope between Hudson and Baltimore Canyons: Geology, v. 10, p. 408-412.

Weber, J.C., Dixon, T.H., Demets, C., Ambeh, W.B., Mattioli, P.J.G., Saleh, J., Selle, G., Bilham, R., and Perez, O., 2001, GPS estimate of relative motion between the Caribbean and South American plates, and geological implications for Trinidad and Venezuela: Geology, v. 29, p. 75-78.

Whipple, K.X., and Tucker, G., 1999, Dynamics of the stream power river incision model: Implications for height limits of mountain ranges, landscape response timescales, and research needs: Journal of Geophysical Research, v. 104, p. 17,661-17,674.

\section{FIGURES}

Figure 1. Geodynamic setting of eastern Caribbean. CRF is Central Range fault. Bold arrow shows relative motion of Caribbean

plate relative to South American plate (from Weber et al., 2001). Light gray area corresponds to Caramba marine survey.

Figure 2. A: Seismic profile illustrating syntectonic fan formed on back limb of fault-related fold. These criteria were used to draw map of recent tectonics shown in B. TWT-two-way traveltime. B: Map of recent tectonics of southern Barbados prism. Numbers along course of channels $a, b$, and $c$ are landmarks labeled on their respective longitudinal bathymetric profile in Figure DR1 [see footnote 1] and Figure 3. Note abandoned channel in northern part of area.

Figure 3. A: Longitudinal profile of channel a and evolution of its morphology shown by occurrence of sedimentary levees and channel-substrate erosion. Numbers above channel profile refer to landmarks in Figure 2. Mean slope of channel is calculated in sliding window of $25 \mathrm{~km}$. B: Seismic profile showing transverse section of channel with sedimentary levees. C: Seismic profile showing transverse section of channel affected by erosion. D: Seismic profile showing transverse section of canyon through frontal folds. Figure 4. A-C: For channels $a, b$, and $c$ in first $60 \mathrm{~km}$ back from deformation front, respectively, comparison of structures inferred from nearest seismic profile, slope (calculated in a sliding window of 3 $\mathrm{km}$ ), and total incision. Characteristic elements of structure (intersections of fault and surface and of hinge line and surface) have been projected on longitudinal profile of canyon. Horizontal distortion occurs owing to sinuosity of canyons. Continuous black line is channel profile; gray line is canyon wall profile. Gray areas on slope curve indicate zone of enhanced slope (>1.9\%). TWT-two-way traveltime. 


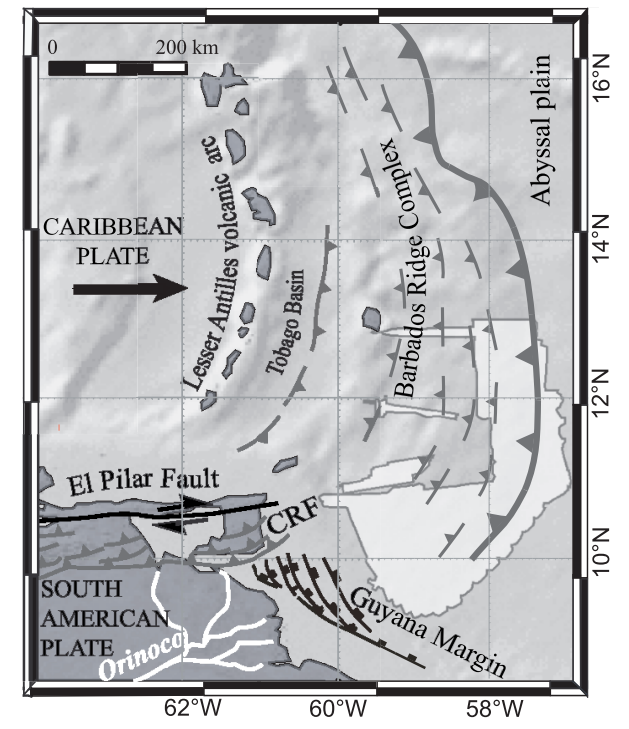

Fig. 1 


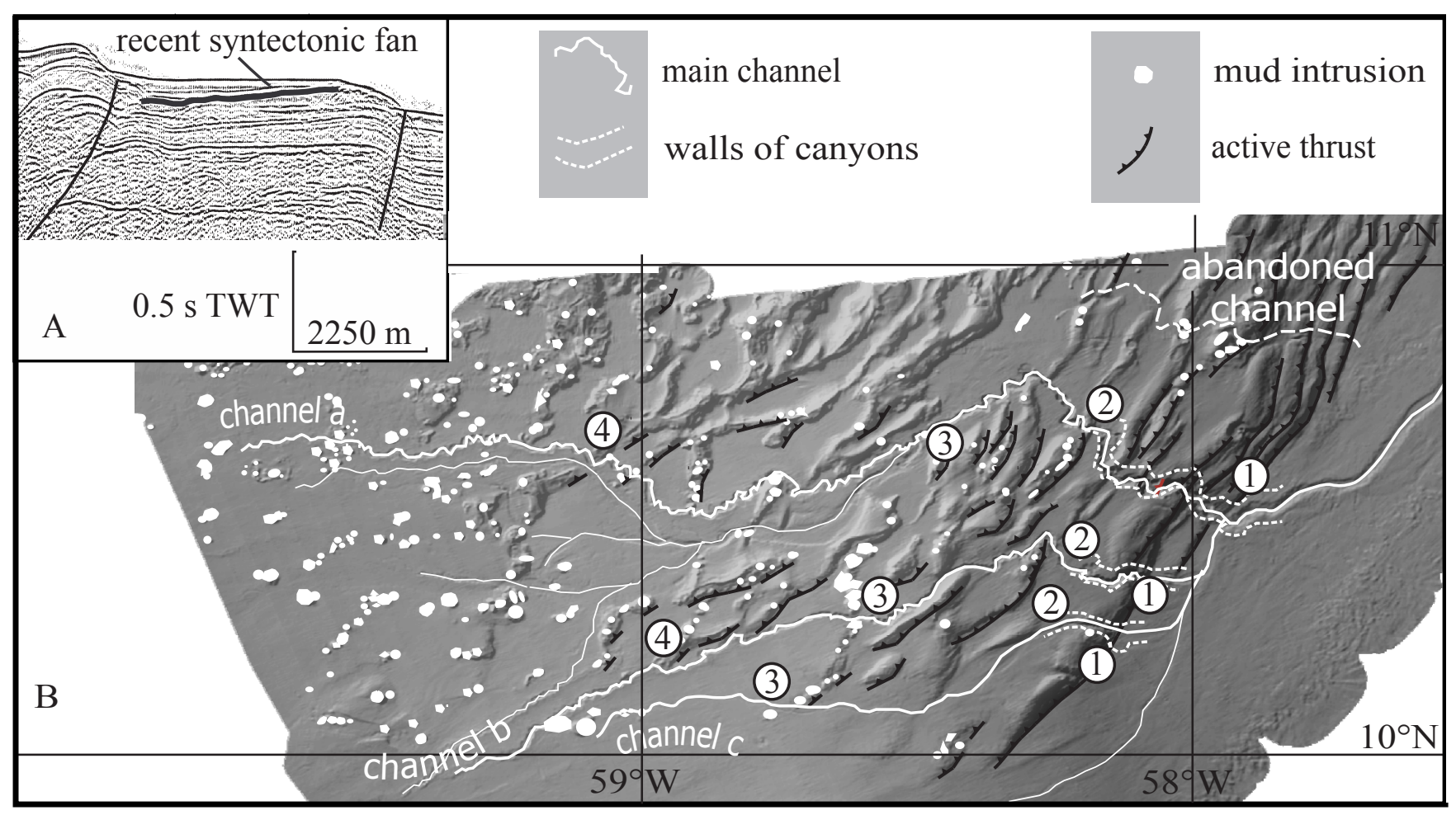

Fig. 2 

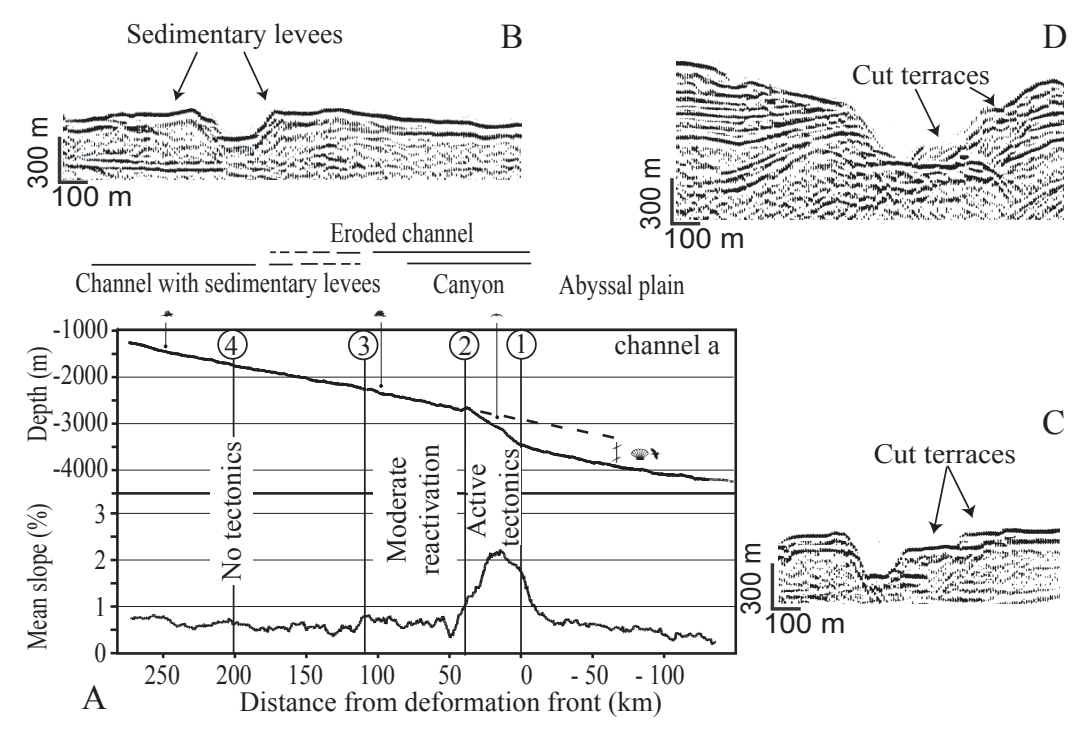

Fig. 3 


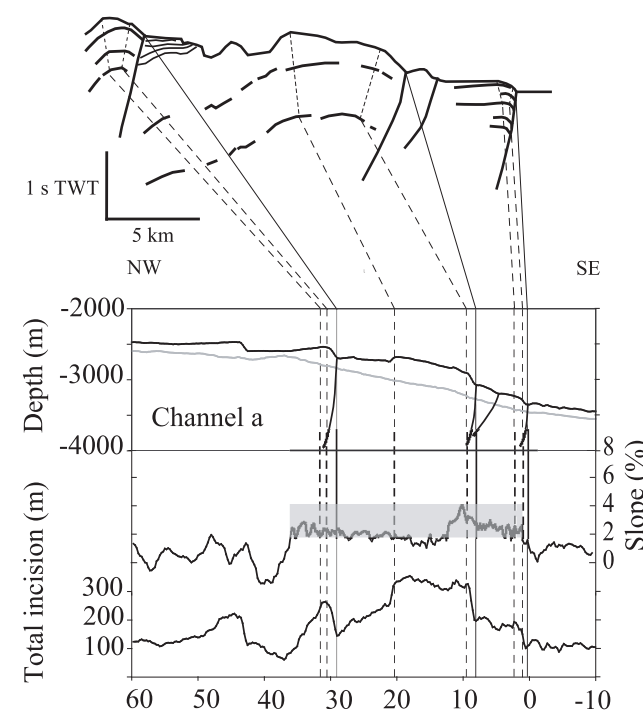

A

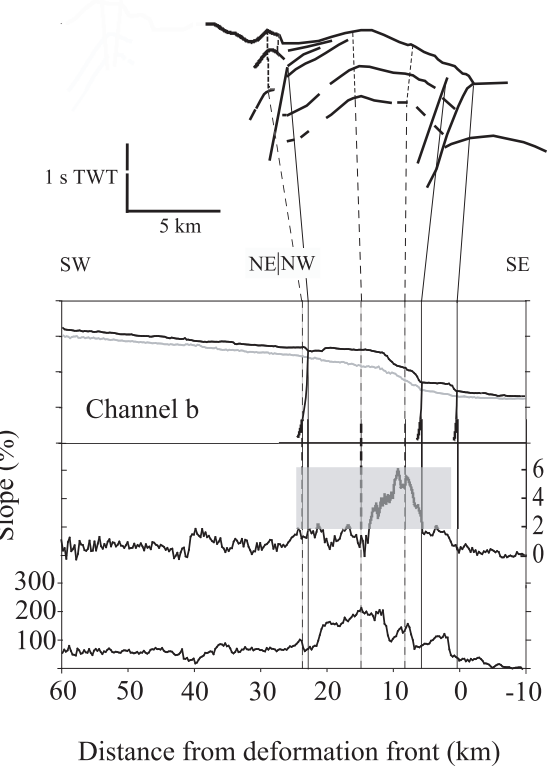

B

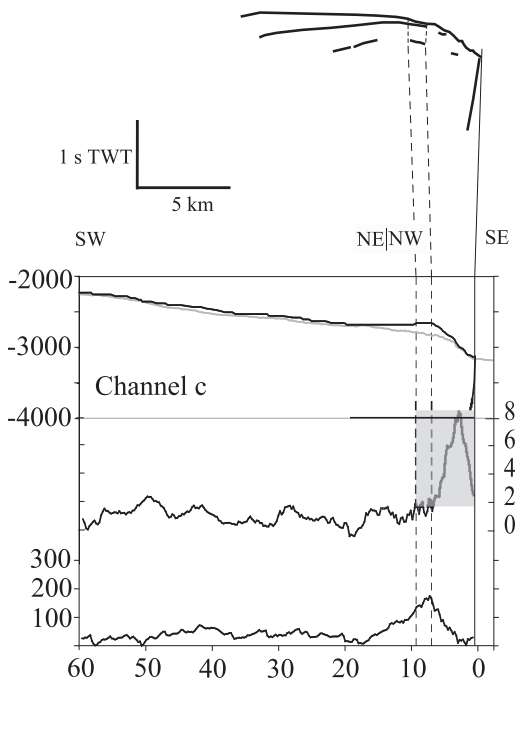

C

Fig. 4 